\title{
COPING STRATEGIES USED BY FAMILY MEMBERS OF INDIVIDUALS RECEIVING HEMODIALYSIS
}

\author{
Fernanda Ribeiro Baptista Marques ${ }^{1}$, Marina Raduy Botelho², Sonia Silva Marcon', Jussara Simone Lenzi \\ Pupulim ${ }^{4}$
}

\footnotetext{
${ }^{1}$ Doctoral student of Nursing at the Universidade Federal de São Paulo. São Paulo, São Paulo, Brazil. Email: fernandarbm@hotmail. com

${ }^{2}$ M. Sc. in Nursing. Maringá, Paraná, Brazil. Email: raduybotelho@gmail.com

${ }^{3}$ Ph.D. in the Philosophy of Nursing. Professor of the Undergraduate and Postgraduate Courses in Nursing, Universidade Estadual de Maringá (UEM). Maringá, Paraná, Brazil. Email: soniasilva.marcon@gmail.com

${ }^{4}$ Ph.D in Nursing. Professor of the Undergraduate Course in Nursing, UEM. Maringá, Paraná, Brazil. Email: jslpupulim@bol. com.br
}

\begin{abstract}
This descriptive, qualitative study aims to identify the coping strategies used most by the family members of patients with chronic kidney disease receiving hemodialysis. The data were collected through interviews, with the Coping Strategies Inventory questionnaire administered to ten family members, and were submitted to descriptive statistics and to thematic content analysis. The strategy used most was escape-avoidance, demonstrating that the family members prefer not to face the situation. The second most-used strategy was social support, ratified by the fact that they stated that they talk with other persons and professionals, seeking information about the problem, and because they accept the support received positively. The third was problem resolution, represented by the attitude of accepting responsibility for the care, either through strong affective bonds or through a feeling of responsibility established prior to the disease. The families use coping strategies of different intensities, while, nevertheless, indicating involvement and major participation in the care for the patient.
\end{abstract}

DESCRIPTORS: Renal dialysis. Behavior. Psychological adaptation. Chronic disease. Family relationships.

\section{ESTRATÉGIAS DE COPING UTILIZADAS POR FAMILIARES DE INDIVÍDUOS EM TRATAMENTO HEMODIALÍTICO}

RESUMO: Estudo descritivo, de natureza qualitativa, que objetivou identificar as estratégias de enfrentamento mais utilizadas por familiares de pacientes com doença renal crônica em hemodiálise. Os dados foram coletados por meio de entrevista, com aplicação do Inventário de Estratégias de Coping a dez familiares, e submetidos à estatística descritiva e à análise de conteúdo temática. A estratégia mais utilizada foi fuga e esquiva, demonstrando que os familiares preferiam não enfrentar a situação. A segunda estratégia mais usada foi suporte social, ratificada ao afirmarem que conversaram com outras pessoas e profissionais buscando informações sobre o problema, e por aceitarem positivamente o apoio recebido. A terceira foi resolução de problemas, representada pela atitude em assumir o cuidado, seja pelo forte vínculo afetivo ou pelo sentimento de responsabilidade já estabelecido antes da doença. As famílias empregaram estratégias de enfrentamento com intensidades diferentes, porém indicando envolvimento e grande participação no cuidado ao doente. DESCRITORES: Diálise renal. Comportamento. Adaptação psicológica. Doença crônica. Relações familiares.

\section{ESTRATEGIAS DE AFRONTAMIENTO UTILIZADAS POR LAS FAMILIAS DE LAS PERSONAS EN TRATAMIENTO DE HEMODIÁLISIS}

RESUMEN: Estudio cualitativo, que trató de identificar las estrategias de afrontamiento empleadas por las familias de los pacientes con insuficiencia renal crónica en hemodiálisis. Se aplicó el Inventario de Estrategias de Afrontamiento y una questión abierta con diez familiares. Los datos cuantitativos fueron sometidos a procedimientos estatísticos y análisis de contenido cualitativo. La estrategia de mayor utilización fue el escape y evitación (oito), lo que demuestra que los miembros de las familisa preferían no tener que enfrentar esta situación. La siguiente estrategia fue utilizada más apoyo social, ya hablé con otras personas y profesionales que buscan información sobre el problema, y aceptar el apoyo positivo recibido. A terceira foi resolução de problemas, representada pela atitude em assumir o cuidado, seja pelo forte vínculo afetivo ou pelo sentimento de responsabilidade já estabelecido antes da doença. Familias de las estrategias de afrontamiento empleadas con diferentes intensidades, pero mostrando una gran implicación y la participación en el cuidado del paciente crónico.

DESCRIPTORES: Diálisis renal. Conducta. Adaptación psicológica. Enfermedad crônica. Relaciones familiares. 


\section{INTRODUCTION}

It may be observed, in developed and developing countries alike, that the demographic and epidemiological transition is causing changes in the situation of the population's morbidity and mortality, thus causing an increase in the incidence and appearance of chronic diseases. Indeed, Chronic Noncommunicable Diseases (CNCDs) are a global problem and a threat to health and to human development. ${ }^{1}$

Chronic disease is defined as permanent or of long duration, and due to pathological changes is considered incapacitating, requiring long periods of treatment/control and rehabilitation. For this reason, these diseases are the targets of more studies by health professionals, as their chronic nature causes concern due to their high incidence and prevalence both in first world countries and in those in development. ${ }^{2}$

Among the most common chronic diseases, Chronic Kidney Disease (CKD) initially appears with a diagnosis of irreversible and progressive loss of kidney function, with damage to glomerular filtration, with metabolic products accumulating in the blood as a result. In this regard, the chronic renal patient, due to having an incurable disease, faces long-term palliative treatment, aiming to prolong survival, while nevertheless causing her pain and suffering and provoking changes with major impacts, above all, on the lifestyle: and, consequently, reducing quality of life for both the patient and her family. ${ }^{3}$

The appearance of a chronic disease within the family causes family members to experience a series of transformations, but their responses depend on the profile of the ill person, such as age and sex, on some stressing factors, on ways of coping, and on the family's beliefs. ${ }^{4}$

For dialysis to be undertaken, the individuals' lifestyle needs to change. Adaptations and changes are necessary in their social environment, and varying feelings are experienced, such as conflicts, frustrations, guilt and depression. Consequently, members of their families have their energies "sucked out of them" because they are more vulnerable, or are in a scary situation, when the chronic disease is not controlled. It is emphasized that each family has specific characteristics which make it unique in its way of being and, due to this, it presents distinct behaviors in relation to the need for adaptation in cases of a member becoming chronically ill. With time, however, there is a tendency for restructuring of the family with a view to helping the individual in the process of being ill. ${ }^{5}$

The chronic condition and the hemodialysis treatment are, therefore, sources of stress, as they cause problems such as social isolation, loss of employment, dependence on Social Security, partial or total impossibility of locomotion or going out, reduction in physical activity, the need to adapt to loss of autonomy and change of body image as well as an ambiguous feeling, between fear of living and fear of dying. ${ }^{6}$

These problems can trigger a stress reaction in the individual, which is only possible through a stimulus termed a stressor. Each individual interprets this in their own way, based on the meaning attributed, through previous experiences and also through the cognitive function which transforms this stimulus into a stressor. ${ }^{3,7}$

The individual and family alike can use coping strategies so as to control the stress, and the way that these choose these is determined by resources - both internal and external - including responsibility, health, support, beliefs, material resources and social skills. ${ }^{8}$

Thus, the family is the first party responsible for care for the health of its members, and it is important to know the different means that it uses to deal with a stressful situation. In this case, hemodialysis makes it possible to elaborate a care plan that is more specific to the needs of the patient and of the family itself, contributing to the implementation of more efficacious nursing interventions and actions, given that it is the role of the nurses to guide and prepare the patient for self-care. Thus, this study's objective was to identify the coping strategies used most by the family members of patients with chronic kidney disease receiving hemodialysis.

\section{METHODOLOGY}

This is a descriptive, qualitative study, undertaken with family relatives/caregivers for patients with chronic kidney disease receiving hemodialysis treatment in the Hemodialysis Center of a philanthropic institute in the city of Maringá in the Brazilian State of Paraná (PR).

The study included the family members of patients aged between 18 and 50 years old, this being considered a phase in which the individuals are most active and have great expectations in relation to their own lives. In order to identify possible 
informants, visits were made to the hospital's Hemodialysis Department over the course of one week and during all three shifts (morning, afternoon and night), with the aim of establishing contact with the patients, providing information regarding the study, and obtaining authorization to invite their family member/main caregiver to participate in the study. The family member was initially approached by telephone and invited to participate in the study. In cases of agreement, the interview was arranged according to the participants' availability.

When the study was undertaken, 133 patients were being attended in the institution, of whom 34 met the age criteria established; three, however, refused to provide the address of a family member, and a further four did not appear at the hemodialysis sessions during the period arranged for data collection. Of the 27 patients who provided the address of a family member, only 12 lived in Maringá, and two of these declined to participate in the study, with the result that ten family members of patients in dialysis participated.

The data were collected in July 2010, during single visits to the family members' homes, when a semi-structured interview was held and the Coping Strategies Inventory was administered. ${ }^{9}$ The questionnaire used in the interviews aimed to collect socio-demographic data and included the following guiding question: 'what did you do when you found out that your family member would be dependent on hemodialysis?' The response to this question was recorded and, later, transcribed in full, the interviewees' natural form of speech being preserved.

The Coping Strategies Inventory ${ }^{9}$ was administered at the end of the interview. This instrument, adapted and validated for the Brazilian culture ${ }^{10}$ is made up of 66 items which address thoughts and actions which people use for dealing with internal and external questions in relation to a specific stressing event, in addition to "distractive" questions (21 items), which are not scored on the conversion scale. The inventory's focus is on the coping process for a particular situation, and not on coping as a characteristic or description of the persons in question. ${ }^{9-10}$

The scale addresses eight factors, also termed domains or categories of coping strategy, namely: Factor 1 - Confrontive Coping (made up of six items); Factor 2 - Distancing (seven items); Factor 3 - Self-control (five items); Factor 4 - Seeking social support (five items); Factor 5 - Accepting responsibility (seven items); Factor 6 - Escape-avoidance (two items); Factor 7 - Planful problem-solving (four items); and Factor 8 - Positive reappraisal (nine items).

All the questions are scored on a Likert-type scale, varying from 0 - I did not use this strategy; 1 - I used it a little; 2 - I used it quite a lot; through to 3 - I used it very much, with the maximum score possible being 198 points. The data obtained through the administration of the inventory were recorded in a Microsoft Excel 2007 database, and statistical procedures of descriptive analysis were undertaken through simple frequency and percentage frequency.

For analysis of the quantitative data, a comparison was made of the scores obtained in each factor, with the strategies which obtained the highest scores being considered those most used. For the qualitative data, on the other hand, the interviews were transcribed in full and later subjected to a process of content analysis, ${ }^{11}$ composed of a phase of pre-analysis and exploration of the data; followed by systematic organization with identification of interference variables and meanings which led to indicators, which were grouped according to similarity and discussed in the light of other studies.

The study was undertaken in agreement with the guidelines regulated by Resolution 196/96 of the Brazilian Ministry of Health, and its project was approved by the Standing Committee for Ethics in Research with Human Beings, of the State University of Maringá (Opinion n. 315/2010). All the participants signed the terms of consent in two copies, and in order to safeguard their identities, were identified with the letter "I" (for 'interview') and a number indicating the order in which the interview was held.

\section{RESULTS AND DISCUSSION}

The ten family members in the study were aged between 20 and 61 years old (mean of 40 years old) and all were female, showing that in spite of the transformations which have occurred in family characteristics and roles, few changes are observed in relation to the woman's caregiving function. Some of the reasons for which the women become the main caregivers are: being married to the patient, the absence of another individual to take on the role of caring, moral obligation related to religion or culture, and financial conditions. ${ }^{12}$

In relation to the degree of kinship with the person receiving hemodialysis, three were wives, 
two were mothers, two were sisters, two were daughters and one was an aunt. It was ascertained that the family unit is not always the point of reference for the patient, as in some cases, sisters and aunts take responsibility for the care. In relation to marital status, five were married, one was separated, three were single and one was a widow; they had various occupations such as housewife, secretary, administrative assistant, teacher, maid, and retired.

In relation to health care, only two families did not use the Unified Health System (SUS), and mentioned fixed costs with medications/health plans, between $\mathrm{R} \$ 100.00$ and $\mathrm{R} \$ 1,000.00$. The families' mean income was $\mathrm{R} \$ 2,000.00$, this resulting from the contributions of one to three people. In addressing this question, various families reported that they still had not managed to obtain sickness benefits for their loved ones, which reduced the family budget. The changes in income were broadly coupled with the family dynamic, which in its turn has a significant impact on the family in such a way that the financial question is decisive in the practice of caring, leading the people to make changes in the home and in family life. ${ }^{13}$

All the interviewees reported a strong affective bond with their relatives, attributing an important and representative role in the family system; two even mentioned that they did not sleep well and needed medication, due to their worries and tension from this situation. In speaking about this situation of coping in relation to their family member's hemodialysis, the interviewees reported all their experience and needed to discuss the situation in detail.

In relation to the score produced through the administration of the inventory, it was ascertained that only four subjects used fewer than $50 \%$ of the strategies, with the lowest score obtained being 70 , and the highest 143; the mean of the scores was 108. This shows that the majority of the family members interviewed used approximately half of the strategies presented in the inventory as coping resources.

In relation to the evaluation of the efficacy of the coping, it is necessary to observe not only the resolution of the problem, but also the ability to control it. This model of approach refers mainly to situations which are impossible to resolve and which are permanently stressful, as in the case of the chronic illnesses, in which the absence of possibilities of a cure requires more strategies for control of the emotions and the situation than confrontive actions. Based on data in the literature, coping has been focused on emotion, as a strategy which is favorable and efficacious in coping with stressful situations. ${ }^{12}$

In the case of chronic illness in children, it is common for the parents to use the strategy of distancing from the stressful situation with greater frequency, which is configured as an alternative due to the feeling of impotence. At the same time, the parents seek to adopt attitudes to minimize the emotional shock resulting from the perception of their own limitations, also investing in adaptive strategies in the search to maintain the family balance. ${ }^{14}$

Table 1 presents the percentages of the responses to the Coping Strategies Inventory's eight factors of evaluation, in which one can observe that the factors used most by the caregivers were escape-avoidance (65\%), agreeing with the results presented by another study undertaken with 14 families which had members receiving inpatient treatment in Intensive Care Units. ${ }^{15}$ In the same regard, another study undertaken with family members of patients in ICU, using the Jalowiec Coping inventory, identified that the style of coping used most was supportant $(57.7 \%)$, which refers to the use of support for coping with problems, followed by optimism (17.5\%) and self-reliance $(8.75 \%) .{ }^{16}$ These results coincide with those found in this study, given that both problem resolution $(60 \%)$ and positive reappraisal (52\%), coping styles which are similar in the two inventories, were also indicated as significantly-used ways of coping (Table 1).

The differences observed in the choice and use of the coping strategies probably result from the variation in the interviewees' profiles, the period in which they received treatment, and the stage of the disease, and the extent to which such factors influence the concept regarding the disease. It is believed that the same family members interviewed in this study, on other occasions during the progression of the disease and phase of treatment, could - to a greater or lesser extent - use coping styles different to those indicated during the administration of the inventory. Furthermore, it is understood that generally speaking the people use the resources available at specific moments, whether these are material and/or human, for coping with or overcoming specific stressful situations. 
Table 1 - Distribution of the percentages of responses indicated for each one of the factors of the Coping Strategies Inventory. Maringá, Paraná, 2010

\begin{tabular}{lcccc}
\hline Factor & Didn't use $\%$ & Used little $\%$ & Used quite a lot \% & Used very much \% \\
\hline Factor 1 - Confrontive & 60 & 6 & 10 & 24 \\
Factor 2 - Distancing & 59 & 10 & 10 & 21 \\
Factor 3 - Self-control & 44 & - & 10 & 46 \\
Factor 4 - Social support & 20 & 8 & 11 & 61 \\
Factor 5 - Acceptance of responsibility & 46 & 8 & 22 & 24 \\
Factor 6 - Escape-avoidance & 20 & 10 & 5 & 65 \\
Factor 7 - Problem resolution & 8 & 7 & 25 & 60 \\
Factor 8 - Positive reappraisal & 18 & 8 & 22 & 52 \\
\hline
\end{tabular}

So as to understand the strategies better, the caregivers' reports were analyzed and compared with the responses of the inventory, such that excerpts from the reports can illustrate the discussions.

\section{Feelings and actions regarding the under- taking of hemodialysis by a family member}

It is observed that the fact of undertaking hemodialysis treatment can trigger various reactions which depend on factors such as family members' concepts and prejudices, level of education, culture, and also the way that this family member was approached by the health team on the occasion when the need to undertake hemodialysis was defined. Caring for a family member with CKD is a very difficult experience for the family as it involves a chronic illness which requires continuous care, with low quality and expectancy of life. ${ }^{4}$

It was ascertained that on the occasion of discovering that the family member in question had the illness, the strategy used most by the family members was escape-avoidance, showing that they would like, in some way, not to have to face this situation. In parallel, one can note in the reports the effort made by some family members to avoid or circumvent this stressful factor, also expressing the wish for a rapid or magical solution for the situation.

We have faith, for God nothing is impossible. For so many people, the kidney resumed functioning and they stopped having to do [hemodialysis] [...] (I3b).

[...] I hope that the miracle happens of him managing to receive a kidney. But for me this would be a miracle [...] (I7b).

Even now I ask myself, my God, why did this happen to me? But I never abandoned ship, I always carried on, always, to give him strength. Because I knew that I had to be stronger than him (I7b).
It was observed that the strategy of escape-avoidance did not appear explicitly, but was coupled with the defensive denial, articulated with positive illusions, functioning as a means of escape against the extreme stress; in this way, translating as persevering and optimistic attitudes for the resolution of the problem. Apparently, according to the report of $\mathrm{I} 7 \mathrm{~b}$, there was a positive reappraisal of the situation, with acceptance of responsibility.

It was also noted that the use of escape through fantasy could be related to the lack of knowledge and difficulty in coping with the chronic nature of the disease. This factor may be observed in the account below, which expresses ignorance of the treatment:

in the beginning, I didn't understand it correctly, I thought he would have to receive inpatient treatment. I was terrified, I was in despair, but then we talked, they explained what you have to do, the apparatus attached up to him. Because in the beginning there was the catheter and I was scared, I had never seen that before, nobody in my family had had this, I thought that it would stay in him all the time, I thought, my God, it's going to be difficult. Then they explained that it is only for a while, that later you have to come to do it, that it's no big deal, that life can be normal, and this calmed us down, things calmed down (I3b).

The people, even though knowing little about the disease, instinctively use the notion that it is good or bad, demonstrating that they have the ability to judge and that they are able to preserve the life of the individuals and of their family in the perspective of the care, the practical knowledge, the cautiousness and the consideration. ${ }^{4}$

Although the feelings of denial and hope predominated in the reports, Table 1 shows that six family members indicated that they had not adopted the strategy of distancing; on the contrary, they neither withdrew from the situation nor ceased being concerned about it. That is, the fam- 
ilies became closer to the circumstances, making all the effort necessary, so as to adapt to the new situation. In this way, the members altered and/ or adapted various aspects of their lives, such as, for example, habits and routines:

[...] before, if I had to leave the house or had to wash clothes or clean the house, I had to get everything tidy in order to go out, I could never leave anything for later when I returned. But with his disease, I have let things go, let the house go, so many times. He lived here with me for five months, and there were so many things to do for him, that I dropped everything (I9b).

It may be perceived that, implicitly, the acceptance of responsibility for the health and life of the individual receiving hemodialysis occurs normally for the family members, in spite of the need to change domestic routines, include a new member in the family, and even change city, seeking social support. These observations reinforce the responses related with those indicated with the greatest frequency in the inventory.

[...] and that is when we moved here [...] (I2b).

I brought [brother's name] to live with me, because I think that he needs more special care, it was difficult [...] (I8b).

I wanted to bring him to Parana, because in Rio de Janeiro things are very difficult, whereas here we know the people, and there everything is very far away, difficult. So, he came to Maringá and went straight to the hospital (19b).

Among so many factors which form part of family coexistence, coping with illnesses is one of those which must be understood as part of this experience, being characterized by a variety of acts, behaviors and feelings. It is important to emphasize that the process of coping with the disease in the family depends on some factors such as the family's stage of life, the role performed by the ill member in the family, the implications which the disease's impact causes in each one of them, and the way the family organizes itself regarding the disease. Family re-adaptation - the situation in which all the members come to perform tasks and take on roles in such a way as to permit the smooth functioning of the family system - demonstrates good adaptation to the situation. ${ }^{5}$

In this context, the person responsible for caring for an ill member is also charged with caring for all the other family members, whether in education, their food, or leisure activities. ${ }^{5}$

Our eating habits changed. I had to change salt use gradually, because I always used a lot, and we like it. Sometimes we forget, but remember that the person with a problem is here [...] (I3b).

When you go to the beach, first you have to ring the hospital which does hemodialysis to see if there is a space, so, that is to say, we learn, you know, to live with this, but in the beginning it's difficult [...] (I8b).

Other studies have also observed that the presence of a chronic disease requires a series of changes in the family structure, for there to be adaptation to the new needs resulting from the health problem. The changes which occur due to the presence of CKD and its treatment affect not only the ill person, but all the people around them. ${ }^{5,13}$

By contrast, the family members also manifest some negative feelings and attitudes, demonstrating a wish to forget the unpleasant situation, as if refusal to have contact with the de-structuring fact were capable of resolving the problem.

[...] I knew the traumatic side of the situation more than the beneficial side. So, I - in particular - had to struggle against the trauma which I had. It's not easy, is it, young lady? [...] (I11b).

[...] ah, I slept. I slept for about three days in a row. So much so that I left the hospital and even now I don't remember how. I slept a lot, a lot, a lot, I think for approximately a month [...] (I8b).

Even with all the stress of the discovery and confirmations of the illness, and often, the feeling of denial followed by anger, $60 \%$ of the responses indicated that various family members do not use confrontation as a strategy, as the majority did not demonstrate anger, neither at the causes of the problem nor at other people, and much less withdrew from people/situations in general.

We are not angry, we are sad [...] (I11b).

We are having to be patient, I asked my children to be patient. They think it is that he wants attention [...]. Even I, who was not a patient person, learnt to be so, because the disease doesn't choose anybody, today we are here and tomorrow we might be in that person's place (I3b).

Avoiding facing up to the situation can mean the use of challenging, impulsive and aggressive attitudes, perhaps as a way of trying to overcome the situation, ${ }^{13}$ or the exercising of self-control, which corroborates with $46 \%$ of the responses to the inventory. However, in some cases the family member describes feelings and manifestations such as anger and aggressive ways for altering situations, so as to resolve problems.

I'm angry with his doctor to this day. I look for somebody to blame, and I still blame him now. I 
didn't have experience, and he didn't know how to advise me (I7b).

[...] We only waited nine hours for him to be hospitalized [sarcasm], I had to face up to the security stuff, he was lying down outside on the bench from so much pain. Those enormous buildings [...]. I said: if anything happens to my brother, I'll prosecute the hospital because this is negligence. He was in terrible pain because he needed to pass urine and couldn't. They had to catheterize him, and took out 2 liters. He was in hospital for 25 days, nobody discovered the problem, he was catheterized the whole time until he came to Maringá. He caught an infection which could've killed $\operatorname{him}(\mathrm{I} 9 \mathrm{~b})$.

This reaction was not related only to the non-acceptance of the disease, but also to the late diagnosis, and to delays in the attendance. In some families, this situation provoked attitudes of hostility and/or aggression regarding some services or professionals, at the same time as it reflected the perception of their own impotence regarding the situation.

\section{Seeking emotional support and stability}

The family members do not react to a chronic disease in the same way, especially when it is a limiting disease, whose treatment is complex, requiring frequent commutes and therapy involving sophisticated equipment. In addition, each member or each family has beliefs, values and principles relating to illness, and experiences them differently. This fact reinforces the family members' need to seek resources which helps them to deal with the demands made by the disease, without risking affecting the disease's progression and without affecting the family as a system. ${ }^{13}$

As a result, self-control, which includes efforts for regulating one's own feelings, thoughts and actions, the use of rationality and self-sufficiency, was reported by $46 \%$ of the family members as a way of facing the situation, above all in not letting one's own emotions influence the situation.

[...] I cry when I want to, I complain, but not to him, for him I always try to be positive. Recently he said: 'Ah, Mom, I am at an age when things have to happen now, and if they don't, I don't know what will be of my life'. There is light at the end of the tunnel, and I can see it. But of course, sometimes I complain, I cry, sometimes we can't stand it. But for him, no. Here at home, never. I try to be stronger than the two of them together [her two sons who live with her] (I7b).
The closest family member experiences situations which teach her to coexist with the suffering of the other, on most occasions having to disguise or hide her own feelings, which - almost always - are emotional pain, as they feel impotent, while being responsible for doing everything, even though often they don't have the knowledge or the preparation for this. ${ }^{17}$ However, the presence of love, tranquility and dedication can cause the suffering and distress caused by the concerns to be mitigated, both for the caregiver and for the patient, favoring more effective care.

This resource emerged from the wish to maintain emotional control and not to show loss of heart or failure, even more so in front of the patient or the rest of the family, as the role of caregiver was perceived as synonymous or coupled with the presence of strength and stability for these persons, using self-control as a coping strategy.

Nevertheless, a considerable proportion of the family members' responses (44\%) indicate the non-use of this strategy. They mention allowing the others to know of the true situation, although they always seek to see the positive side arising from the illness.

The best thing which happened was moving here and getting to know new people (I2b).

Due to having experienced an extremely stressful situation, the family members undergo ambiguous experiences, emotions and feelings. In such an improvement, they tend to transmit positive aspects to the patient, controlling their emotions so that they may find solutions to the situation. ${ }^{13}$ The maintenance of the family's emotional structure, however, may also be related to social support strategies, represented in $61 \%$ of the family members' responses, given that they conversed with other people about the problem and sought professional help and further information regarding the situation, as well as accepting peoples' support positively.

God, we always relied on each other, a little here, a little there $[\ldots]$ (I7b).

I was very stressed, very tired, a lot of mental preoccupation, so I went to the doctor and the psychiatrist. I'm taking medication for anxiety and in order to sleep. I'm under a lot of tension, this problem has really affected my metabolism, but now I'm okay (19b).

This house's landlady always helps us, our brothers from the church also always help, since we moved here. We don't need to buy fruit or vegetables. This is the most important thing, because we don't have any 
family, we don't have children, we rely on good people, good neighbors (I2b).

With the aim of finding support and external support as bases for the feelings of protection and relief, this strategy was represented by the help of persons from the social support network, such as friends and relatives and others. These reports endorsed the responses indicated in the inventory by the family members interviewed.

\section{Facing the situation and adopting coping strategies}

The routine, like the stressful experiences of living side-by-side with the chronically ill person, led the family to re-evaluate its knowledge and practices, constructing different meanings, such as changes in the standards of life and actions which enabled them to adjust to the suffering, reviewing their dreams and expectations in the light of the reality of the illness. In this context, the family members take responsibility for the care, learning to seek resources which facilitate these changes, both in the environment and among the people with whom they live. ${ }^{18}$

Thus, the family members also chose to use the factor of problem resolution $(60 \%)$ to cope with the disease, which consisted of the description of actions, planning, creativity, active participation and seeking solutions for the problem, so as to do what is possible to help the situation, without counting the cost. This strategy was represented by the attitude of the family member interviewed in taking responsibility for the care, either through the strong affective link or due to the responsibility for the family member, established prior to the start of the illness.

There were no days off and no weekends, it was a struggle. What we went through with him was very difficult. Always doing whatever was needed for him, I became involved in his situation, I committed myself to his state and always did things willingly, wholeheartedly, whatever is necessary, I do it for him (I9b).

I do whatever's necessary. My son is alive because I did this [...] (I7b).

We tried to give support for what he needs, even going beyond our abilities. Everything is there for him, food, tranquility at home, we try to save him from worrying, it's even bad, but we try to save him from worrying. Not causing him more stress than he already has, you know? And also not to speak much about the subject, you know, 'I'm here if you need me' [...] (I10b).

This process is related to the adherence to the treatment and coping with the situation, and with the family member's active participation through creative actions to overcome the adversities, which required a flexible emotional structure, to identify the possibilities for helping the patient, other members of the family, and oneself. This dynamic is reflected in the availability to be ahead with the care, either through believing in one's potential for the function, or through having been elected by the family as the person best prepared for this position or for taking on the main role in decision-making.

Even considering all of the families' difficulty in experiencing the illness of a loved one ${ }^{19}$ and all the obstacles for dealing with the treatment process, $52 \%$ of the responses indicate that the family members positively re-evaluated the situation, re-discovered their importance in life, made personal changes, indicated personal growth, and developed new beliefs.

[...] but I think I learned a lot, I had to learn to be able to help and even to accept, even not wanting to $(\mathrm{I} 8 \mathrm{~b})$.

I had to become stronger, to let my strength increase. Can you imagine if he was there needing help, and you standing there, not being able to? (I7b).

Through this strategy, one can notice that there was an internal reorganization of the facts, which allowed those involved to find support, think of solutions, and value the positive aspects of the situation, with the intention of mitigating the severity and reducing the occurrence's emotional load..$^{10}$ This is evidenced when they mention seeking relief in prayer and in religious beliefs.

[...] I prayed a lot. Every night I pray to God, but it is difficult (I8b).

I pray for him a lot, the time is set by God, I leave everything in His hands. He is covered by the grace of God (I9b).

Thus, the strategy of positive reappraisal met one need of the family, by giving meaning to the crisis which was being experienced, after the various questions which required answers. ${ }^{19}$ As a result, in order to promote adaptation to new challenges imposed by the disease, the family members find satisfactory meanings in the adversity and can rely on spiritual practices and beliefs to overcome situations, cope with changes and achieve quality of life. Through prayers, participation in rituals and maintenance of belief, the family members recover, as these meetings provide comfort and hope that the situation may improve, leading them to accept the situation from a more flexible 
viewpoint. ${ }^{20}$ One study undertaken to ascertain the association between the presence of chronic problems and the importance given to spirituality, religiosity and personal beliefs in this circumstance, associated with quality of life, identified that such factors have positive importance and that they must be considered in the interventions, in order to improve these patients' quality of life..$^{21}$

Thus, it is inferred that, at least apparently, the support tools provided by spirituality covered most of the family members' emotional needs, given that the doctors attended the patient's clinical needs.

\section{FINAL CONSIDERATIONS}

The family members studied showed that they used the coping strategies in various ways and with varying intensity, although with involvement and with great participation in the care for the chronically-ill person. This reveals that the families seek to resolve the problems effectively and focus on the situation positively. The results related to the administration of the inventory reinforce the reports from the interview, especially when they describe the experiences with the disease and the hemodialysis, favoring the understanding of the process of coping with kidney disease experienced by the families.

It should be emphasized that some family members referred to the work of the health professionals, principally the nurses, emphasizing the role which they had in the process experienced by the family and coping with the disease, pointing to the importance of greater involvement in this process on the part of the health team. This fact, on its own, reinforces the need to continue investigating and investing in professional training, so as to improve the quality of the care and the support for the family members, having as a goal the instrumentalization of the patient and the family, making them better prepared and informed regarding the interfaces of the disease and the treatment, thus facilitating the process of coping and adapting to the condition of chronic illness.

Finally, the strategies used most frequently by the family members interviewed emphasized the family's value and efforts in order to act as an emotional and structural - and why not include financial - mainstay for the individual with chronic kidney disease, thus demonstrating, once again, the importance of the health professionals' including and involving the family in the care plan.

\section{REFERENCES}

1. Schmid MI, Duncan BB, Silva GA, Menezes AM, Monteiro CA, Barreto SM, Chor D, Menezes PR. Doenças crônicas não transmissíveis no Brasil: carga e desafios atuais. Lancet. 2011 Jun; 377(9781):1949-61.

2. Brito DCS. Cuidando de quem cuida: estudo de caso sobre o cuidador principal de um portador de insuficiência renal crônica. Psicol Estud [online]. 2009 [acesso 2010 Mai 2010] 14(3). Disponível em: http:/ / www.scielo.br/pdf/pe/v14n3/v14n3a22.pdf

3. Bertolin DC, Pace AE, Kusumota L, Ribeiro RCHM. Modos de enfrentamento dos estressores de pessoas em tratamento hemodialítico: revisão integrativa da literatura. Acta Paul Enferm. 2008; 21(spe):179-86.

4. Paula ES, Nascimento LC, Rocha SMM. The influence of social support on strengthening families of children with chronic renal failure. Rev LatinoAm Enfermagem. 2008 Ago; 16(4):692-9.

5. Santos AL, Cecíclio HPM, Teston EF, Marcon SS. Conhecendo a funcionalidade familiar sob a ótica do doente crônico. Texto Contexto Enferm [online]. 2012 [acesso 2014 Mai 10] 21(4). Disponível em: http://www.scielo.br/pdf/tce/v21n4/19.pdf

6. Madeiro AC, Machado PDLC, Bonfim IM, Braqueais AR, Lima FET. Adesão de portadores de insuficiência renal crônica ao tratamento de hemodiálise. Acta Paul Enferm. 2010; 23(4):546-51.

7. Higa K, Kost M T, Soares DM, Morais MC, Polins BRG. Qualidade de vida de pacientes portadores de insuficiência renal crônica em tratamento de hemodiálise. Acta Paul Enferm. 2008; 21(spe):203-6.

8. Rodrigues AB, Chaves EC. Stressing factors and coping strategies used by oncology nurses. Rev. Latino-Am Enferm [online] 2008; [acesso 2010 Mai 12] 16(1). Disponível em: http://www.scielo.br/ pdf/rlae/v16n1/03.pdf

9. Folkman S, Lazarus RS, Dunkel-Schetter C, Delongis A, Gruen RJ. Dynamics of a stressful encounter: cognitive appraisal, coping, and encounter outcomes. J Personality Social Psychology. 1986; 50(5):992-1003.

10. Savoia MG, Santana PR, Mejias NP. Adaptação do inventário de estratégias de coping de Folkman e Lazarus para o português. Psicol. USP 1996; 7(12):183-201.

11. Bardin L. Análise de conteúdo. Lisboa (PT): Editora Setenta, 2008.

12. Simonetti JP, Ferreira JC. Estratégias de coping desenvolvidas por cuidadores de idosos portadores de doença crônica. Rev Esc Enferm USP. 2008 Mar; 42(1):19-25.

13. Fraguas G, Soares SM, Silva PAB. A família no contexto do cuidado ao portador de nefropatia diabética: demanda e recursos. Esc Anna Nery. 2008 Jun; 12(2):271-7.

14. Coletto M, Câmara S. Estratégias de coping e percepção da doença em pais de crianças com 
doença crônica: o contexto do cuidador. Rev Diversitas Perspectivas En Psicología. 2009; 5(1):97110.

15. Borges KMK. Famílias de pacientes graves internados em terapia intensiva: descrevendo suas estratégias de enfrentamento [dissertação]. Rio de Janeiro: UFRJ, Faculdade de Medicina; 2008.

16. Dreffs FML, Stumm EMF, Winkelmann ER, Ubessi LD. Mecanismos de coping utilizados por familiares de pacientes em terapia intensiva. Rev Ciência Saúde Porto Alegre. 2013 Jan-Abri; 6(1):52-8.

17. Centenaro GA. A intervenção do serviço social ao paciente renal crônico e sua família. Ciênc Saúde Coletiva. 2010 Mar; 15(1):1881-5.

18. Moreno V. Familiares de pacientes em hemodiálise: convivendo com condição crônica de saúde. Rev Rene. 2008 Out-Dez; 9(4):49-56.

19. Caetano JPM, Fernandes MV, Marcon SS, Decesaro MN. Refletindo sobre as relações familiais e os sentimentos aflorados no enfrentamento da doença crônica. Cienc Cuid Saúde. 2011 Out-Dez; 10(4):84552.

20. Moreno V. Familiares de pacientes em hemodiálise: convivendo com condição crônica de saúde. Rev Rene. 2008 Out-Dez; 9(4):49-56.

21. Rocha NS, Fleck MPA. Avaliação de qualidade de vida e importância dada à espiritualidade/ religiosidade/crenças pessoais (SRPB) em adultos com e sem problemas crônicos de saúde. Rev Psiq Clín. 2011; 38(1):19-23. 